\title{
TRENDS IN STATE-CIVIL SOCIETY RELATIONS IN BOTSWANA
}

\section{Monageng Mogalakwe and David Sebudubudu}

\author{
Monageng Mogalakwe is a senior lecturer in the \\ Department of Sociology, University of Botswana \\ $\mathrm{Tel}+2673552678$ \\ e-mail: Mogalakwe@mopipi.ub.bw
}

David Sebudubudu is a senior lecturer in the Department of Political and Administrative Studies, University of Botswana, and a member of the

Democracy Research Project (DRP) of the University of Botswana

P/Bag UB 00705, Gaborone, Botswana

Tel: +267 355 2732; Fax: +267 3170706

e-mail: sebudubu@mopipi.ub.bw

\begin{abstract}
The accolades that have been heaped on Botswana as a shining example of democracy and good governance in Africa have been exaggerated. While Botswana has regularly held elections since its independence in 1966, the post-colonial state's relationship with civil society reveals that some of the institutions of civil society such as labour unions and the independent press/ media have been tightly controlled, in sharp contrast to others, such as human rights or women's organisations. This is because the former institutions are viewed as a threat to the status quo, while the latter are seen as compliant and playing only a legitimising role.
\end{abstract}

\section{INTRODUCTION}

I wonder why the government is only interested in the media industry. Why [is] there a government radio station, television and newspaper, but there is no government supermarket or construction company? 
Botswana has been handsomely praised as Africa's leading example of multiparty liberal democracy and good governance. According to Stedman (1993) the country stands out as an exception that confounds generalisations. Botswana has held regular multiparty elections religiously since independence in 1966. An incident that perhaps underlines why the country is so highly considered occurred in 1999 when then President Festus Mogae had to declare a state of emergency, the only one in the history of Botswana, in order to recall Parliament, which had previously been dissolved, to pass an amendment to the Electoral Act to allow the inclusion in the voters' roll of the names of some 66000 voters. The voters had been excluded when the president issued the Writ of Elections for the 1999 General Election because their national identity cards had expired. Explaining the reasons for the State of Emergency, the president informed the nation that it was not acceptable to him that so many people who had registered to vote could be disenfranchised by a legal technicality (Botswana Government 1999; Sebudubudu 2006, p 196).

For most of its post-colonial history Botswana's economy has grown by an average of 9 per cent - among the highest growths in the world - and in the mid1980s the country was ranked as middle income. Samatar (1999) argues that Botswana has avoided the rampant corruption and mismanagement that bedevil most Third World countries and its exceptional development has taken place in the environment of a genuinely functioning liberal democratic system, in sharp contrast to the case of the Asian Tigers, whose economic miracle took place in the context of political repression. Botswana has also been classified by Transparency International as the 'Least Corrupt', by the Carnegie Endowment for International Peace as the 'Most Globally Integrated', and by Moody Investors Services as the country with the 'Lowest Sovereign Risk Rating'.

It is important, though, that these accolades are not overstated. They derive mainly from Botswana's comparison with those Third World countries where one-party states and military dictatorships have been the order of the day. In this comparison Botswana came out the best, of the worst.

It should also be noted that, since independence, elections in Botswana have been won by the same party, the ruling Botswana Democratic Party (BDP). Among the reasons for this are the use of the first-past-the-post (FPTP) electoral system, in which there is no correspondence between a party's popular support and its parliamentary representation. Thus, while in 2004 the BDP won just about 51 per cent of the popular vote, it took about 77 per cent of the parliamentary seats, while the combined opposition, which won about 49 per cent of the vote, achieved a paltry 23 per cent of seats (Botswana Government 2004).

This paper re-examines Botswana's record in the area of state-civil society relations. It argues that with the advent of the multiparty system in Africa in the 
1990s, including the first ever multiracial elections in South Africa, Botswana's much vaunted democracy and good governance seem to have been overtaken by a growing tide of democratisation on the African continent. A strong and vibrant civil society should be seen as a sine qua non of democracy; and democracy functions on the basis of checks and balances provided in part by civil society. The fact that in Botswana civil society has remained weak calls for a more critical reappraisal that will hopefully lead to a more even-handed approach to Botswana.

\section{THE DEMOCRACY AND CIVIL SOCIETY DEBATE}

Democracy can be defined as the 'rule of citizens' in which the people have the right to participate in the making of decisions that will affect them. This right vests in representatives who are elected at regular intervals.

Diamond, Linz \& Lipset (1988, p xvi) define democracy as a system of government where there is

meaningful and extensive competition among individuals and organized groups for all effective positions of government power at regular intervals and excluding the use of force; a highly inclusive level of political participation in the selection of leaders and policies, at least through regular and fair elections, such that no major social group is excluded; and a level of civil and political parties - freedom of expression, freedom of the press, freedom to join and form organizations - sufficient to insure the integrity of political competition and participation.

According to Balogun (1997, p 237) democracy does not come about because the leaders want it to and is not likely to come about spontaneously unless the forces working for it are properly organised. One such force, and one that is critical to a democratic order, is civil society. Civil society, where it exists and is strong enough, provides checks and balances on the activities of the state. For Diamond (1994, p 5) civil society 'involves citizens acting collectively in a public sphere to express their interests, passion and ideas, exchange information, achieve mutual goals, make demands on the state and hold state officials accountable'. Thus, civil society refers to that realm of social relations and public participation that resides between the family and the state and is given expression in the activities of non-state organisations such as religious organisations; social clubs; social movements; free press and independent media; trade unions; professional associations; employers' organisations, trade unions, the media, and other civil society bodies (Cilliers 2004). According to Cilliers ( $p 43$ ) civil society is 
the social and political space where voluntary associations attempt to shape norms and policies to regulate public life in social, political, economic and environmental dimensions.

Until the advent of Huntington's democratisation 'third wave' (1991) realising these aims was an onerous task in most African countries. This was in part because the relationship between civil society and the state in Africa was not an easy one; it was largely characterised by 'concentration of state power at the expense of civil society' (Schraeder 2000, p 218). Schraeder points out that 'from the 1950s to the 1970s the state-society relationship was marked by the creation of highly authoritarian and centralised states seeking to co-opt or silence those very elements of civil society that had contributed to the independence struggles.' Civil society remained undeveloped even in 'long established' democracies such as Botswana (Osei-Hwedie 2003). In this context, in most African countries civil society was either generally weak or non-existent.

That was then. Since the 'third wave' of democratisation civil society has played a central role (and continues to do so) in ensuring the restoration of democracy (at times) under harsh conditions in a number of African countries such as Kenya, Malawi and Zambia. Gyimah-Boadi (1997, p 278) has noted that 'among the forces that dislodged entrenched authoritarianism in Africa and brought about the beginnings of formal democracy in the early 1990s the continent's nascent civil societies were in the forefront'. Osei-Hwedie (2003, p 1) makes the same point, observing that 'the transition to democracy in Africa, in the 1990s, owes a great deal to civil society's concerted pressure that led to the overthrow of authoritarian regimes'. Zambia is a case in point. 'Zambia's Movement for Multi-Party Democracy successfully pressured the government to bring about substantial reforms' which ultimately led to multi-party elections and a democracy (Zuern 2000, p 96). Despite these achievements, civil society organisations 'have experienced much greater difficulties in actually establishing a new, free and functioning democratic state and society' (Zuern 2000, p 96). With the restrictions imposed on civil society before 1989, its role in promoting more meaningful human rights and democratisation in Africa could be traced from the 1990s onwards. Given this uneasy relationship, civil society needs to protect its own turf by working within the existing constraints.

\section{CIVIL SOCIETY IN BOTSWANA: FOUR CASE STUDIES}

According to Carroll and Carroll (2004, p 333) 'civil society was almost non-existent in Botswana in the late 1980s, but it developed extraordinarily rapidly in both size and influence [in the 1990s]. By the turn of the century, Botswana had an 
active, vibrant and influential civil society.' Civil society grew and developed to such an extent that 'by the end of 1999, [it] consisted of approximately 150 indigenous NGOs, around 50 Community Based Organizations, some 23 trade unions, and a handful of business associations' (Carroll and Carroll 2004, p 352). For Taylor (2003, p 221):

Civil society groups in Botswana are not as fully developed as in other African countries. This reality may be partly attributable to the political and economic stability that has prevailed since independence. Furthermore, the lack of any meaningful 'struggle' for independence and the concomitant absence of a tradition of questioning - combined with an essentially top-down traditional culture of acquiescence before one's superiors - may explain the relative weakness and disorganized nature of civil society.

In addition to these problems the absence of issue-based politics limits the extent to which civil society is able to fill the void left by Botswana's weak opposition parties. Most civil society organisations (CSOs) prefer to stay out of politics as they believe that it is in their best interests to do so (Sebudubudu \& Osei-Hwedie 2005). Holm (1996, pp 101-107) laments the unreliable access to government leaders; the resource constrictions, mainly relating to skilled personnel and finance; and, more importantly, 'the narrow Tswana view of politics' as factors that work against the influence and institutional capacity of CSOs in Botswana. Lekorwe (1998, pp 90-91) blames the weakness of CSOs on the shortage of knowledgeable individuals to administer them and the powerful state, which dominates political interaction. Molomo \& Somolekae (1998, pp 101-102) identify a lack of internal organisational management, lack of proper institutionalisation, lack of democracy and lack of accountability as constrictions making an impact on the capacity of CSOs to discharge their functions. Notwithstanding these constraints some CSOs have played a key role in promoting human rights, development and good governance in Botswana. Among them are Emang Basadi, which advances women's rights; Ditshwanelo, a human rights organisation; trade unions, and the media, especially the independent media. We shall look at each in turn.

\section{Emang Basadi}

Emang Basadi Women's Association, formed in 1986 to champion women's rights, which were generally excluded from the governing process of the country, has been in the forefront of lobbying government to take women's rights seriously, especially since the Beijing Conference in 1995. The association's efforts were 
originally directed to applying pressure on the Botswana government to amend all laws that discriminated against women (Somolekae 1998; Selolwane 2004).

The passing of the Citizenship Amendment Act of 1982, which violated women's rights and discriminated against them, intensified women's efforts to fight exclusion and discrimination. The law, which prohibited Batswana women married to foreign men from passing on their citizenship to their children, was enacted despite the fact that the country's Constitution outlaws discrimination (Somolekae 1998; Selolwane 2004; Osei-Hwedie \& Sebudubudu 2004).

In 1995 Unity Dow, a Motswana married to a foreigner, successfully challenged the Act, thus prompting 'parliament to adopt and pass the Citizenship Amendment Bill which removed all gender biases' (Osei-Hwedie \& Sebudubudu 2004, p 33). When it realised that its efforts were slow in yielding results, Emang Basadi, together with other women's groups, switched to the political empowerment of women. This gave rise to the production of the Women's Manifesto in 1994 (Selolwane 2004; Osei-Hwedie \& Sebudubudu 2004). Somolekae (1998, p 11) noted that the intention behind this strategy was to 'sensitize women about their political rights, encouraging them to vote for candidates who are committed to addressing the issues and concerns of women'. Osei-Hwedie \& Sebudubudu (2004, pp 31-32) observed that the 'launch of the Women's Manifesto in 1994 signified the start of a vigorous campaign to articulate women's rights through demands for equal political participation and representation in public decision making'. However, party loyalty in part worked against the efforts of women's groups.

Despite this, the change of strategy and the efforts of Emang Basadi have paid some dividends. Through lobbying it has succeeded in making women's rights a political issue, thus placing them on the agenda. Following the Dow case, the government 'commissioned a nation-wide study to review all laws that discriminate against women, and also ... ratified international instruments forbidding gender-based discrimination' (Somolekae 1998, p 18). Moreover, Emang Basadi has been successful 'in transforming Botswana's political landscape and culture, and in increasing the number of women in active politics' (Selolwane 2004, p 3). Furthermore, more women have been appointed to decision-making positions, including the judiciary.

Emang Basadi's efforts have also contributed to the enactment of tougher laws against rape, and to the abolition of the marital power, the latter being a significant step in the advancement of gender equality. These efforts and the ensuing changes make the organisation believe that 'without [its] efforts, the government would ignore [women's] rights. The fact that more women have been appointed to decision-making positions and are MPs, [is] testimony[y] to tangible results of [its] lobbying efforts' (Osei-Hwedie \& Sebudubudu 2004, p 32). Emang Basadi has been 'the most vocal and active [organisation], and the one 
that exerted the most pressure on the government and political parties' (OseiHwedie \& Sebudubudu 2004, p 31), in so far as women's rights are concerned.

\section{Ditshwanelo - The Botswana Centre for Human Rights}

In a formally democratic country like Botswana human rights are generally taken for granted. This is in part because the Constitution protects human rights, especially civil and political rights. However, Ditshwanelo-The Botswana Centre for Human Rights has some apprehensions, especially with respect to the rights of the marginalised, and has, since its formation in 1993, been in the forefront of advocacy for their rights. Ditshwanelo 'seeks to educate, research, counsel and mediate on human rights issues, with particular reference to people who are marginalized and disempowered' (www.ditshwanelo.org.bw).

Since its formation its key areas of concentration have been: the death penalty, HIV / AIDS and human rights, indigenous peoples (San), domestic workers, refugees, gender bias, militarism, good governance and the strengthening of civil society, as well as issues of gays, lesbians, and bisexuals (www.ditshwanelo.org.bw).

Maundeni (2005, p 184) argues that 'Ditshwanelo has concerns that the Botswana government is still not committed to the protection of human rights. [Nevertheless] Ditshwanelo has not succeeded in bringing a different orientation in the thinking of government on issues of human rights.' Despite these difficulties Ditshwanelo has made an impact, putting human rights, especially for the marginalised, on the agenda. Through its efforts Ditshwanelo managed, in 1999, to 'obtain a stay of execution for two men' who were on death row (www.ditshwanelo.org.bw). According to Taylor (2003, p 222) 'Ditshwanelo provides a very good watchdog service and has been critical of the government on a number of occasions.' Thus, Ditshwanelo believes that as a result of its lobbying 'the San's rights are now debated, which was not the case previously' (Osei-Hwedie \& Sebudubudu 2004, p 32).

However, Maundeni (2005, p 184) further observes that 'if Botswana cannot change its orientation and adopt a positive attitude towards human rights, globalization will bring in international organizations such as Survival International', which employ 'tough tactics' in their lobbying efforts. The impact of Survival International, which has been a thorn in the government's flesh, has been felt most in relation to the issue of the relocation of Basarwa (San). Partly as a result of Ditshwanelo's efforts 'the San have also become active in spearheading their demands for their rights to land and their traditional way of life. They have [also] been helped by Survival International, which has publicized their plight in the Western world and forced government to wage a public campaign to justify their removal from the CKGR [Central Kalahari Game Reserve]' (Osei- 
Hwedie \& Sebudubudu 2004, p 32). The conflict between the San and the government was resolved recently by a decision of the Botswana High Court in favour of the San.

\section{State-labour relations}

At independence Botswana adopted a Constitution that guarantees and protects the fundamental rights and freedoms of the individual. These rights and freedoms include the right to personal liberty, freedom of conscience, expression, assembly and association. Section 13(1) provides that no citizen of Botswana, except with his or her own consent, may be hindered in the enjoyment of his or her freedom of assembly and association and, in particular, in forming and belonging to trade unions or other associations for the protection of his or her interests.

On the face of it, this section of the Constitution gives the impression that Botswana is indeed exceptional and that unlike most other Third World countries it guarantees workers' rights and freedoms. The truth of the matter, though, is that for most of the post-colonial period state policy towards organised labour has been one of domination and subordination through various control mechanisms, but notably through labour legislation (Mogalakwe 1997). The state imposed manifold restrictions on the ability of trade unions to organise freely, and public sector workers were prevented from forming and belonging to trade unions. It can be argued that the state gave labour rights and freedoms with one hand and took them away with the other. For example, s 13(2) of the Constitution states that no law that imposes restrictions upon public officers shall be held to be inconsistent with the provisions of s 13(1) and $13(2)(\mathrm{d})$ of the Constitution. It stipulates further that the state can also impose 'reasonable conditions' relating to the registration of trade unions.

What are these reasonably justifiable restrictions in a democratic society? Between independence in 1966 and 2004 the government imposed a virtual ban on trade union organisation in the public sector. Tens of thousands of public sector employees - civil servants in central government, local government employees, health workers such as nurses, teachers in both government-owned primary and secondary schools, technical colleges, not to mention the police and prison offices - were prevented from forming and belonging to trade unions (Mogalakwe 1997). This proscription came in through the backdoor, implied only in the definitions of 'an employee', 'employer' or a 'trade union', and 'trade dispute' as contained in various pieces of labour legislation such as the Employment Act, the Trade Unions and Employers Organizations Act (TUEOA), and the Trade Disputes Act (TDA).

According to these Acts (before the 2004 amendments) an employee meant any person who had entered into a contract of employment for the hire of his 
labour, provided that the person was not a public officer or a person employed by public authority, unless he belonged to the industrial class, that is, daily-rated manual workers. An employer was defined by the Act as any person who had entered into a contract of employment to hire the labour of others. The definition included government, but only in respect of those of its officers or servants who belong to the industrial class. The Trade Unions and Employers Organizations Act defined a trade union as an organisation, the principal objects of which included the regulation of relations between employees and employers or employers' organisations, or between employers and employees.

As a result of this legal sleight of hand the Botswana government was able legally to prevent literally tens of thousands of workers from forming and belonging to trade unions on the presumption that these restrictions were 'reasonably justifiable in a democratic society'.

The government also imposed manifold legal constraints on trade union organisations and collective bargaining in the private sector. Until 2004 trade unions were hemmed in by a variety of labour laws such as the Trade Disputes Act and the Trade Unions and Employers Organizations Act. The Trade Disputes Act laid down long and complex procedures to be followed before strike action could be lawful, and empowered the state, through the Commissioner of Labour, to intervene in any labour disputes, even those not reported to him. The Act also created a system of conciliation-mediation-compulsory arbitration to break any bargaining deadlock and further insure that there was no strike action (Mogalakwe 1997). As a result, Botswana has never had a lawful strike although the principle of a legal strike has remained in the statute. The Act was amended in 1992 to allow for the creation of the Industrial Court. However, under s 7 of the Act (as amended) if the Commissioner of Labour fails in his efforts to conciliate and mediate he may issue a certificate authorising the parties to the dispute to take the matter to the Industrial Court. Previously when the commissioner failed to bring the two parties together he could refer the matter to the minister, who had the power to order binding compulsory arbitration.

Although Botswana has been a member of the United Nations (UN) since its independence and a member of the International Labour Organisation (ILO) since 1978, it was only in 1997, some 31years after it had joined the UN and 20 years after it joined the ILO, that Botswana ratified the ILO conventions Convention 87 on Freedom of Association and Protection of the Right to Organize, Convention 98 on Right to Organize and Collective Bargaining and Convention 151 on Labour Relation (Public Service) - which are deemed to be core to trade union rights and freedoms.

The fact that it took the country known by many as Africa's shining example of liberal democracy and good governance that long to ratify the conventions 
raises questions about Botswana's brand of democracy. Just how deep is it and does it extend to industrial democracy? These questions are significant because when a country ratifies a convention or covenant it accepts the solemn responsibility to honour the obligations embodied in the convention or covenant, and thus becomes accountable not only to its own people but to the international community of countries that have also ratified those treaties. The time lapse suggests that Botswana was not ready for this kind of scrutiny.

This observation is reinforced by the fact that while the ILO gives its member states a grace period of one year to correct those aspects of their laws that curtail or infringe the rights and freedoms of workers, it was not until 2003, about five years after the lapse of the grace period, that the government began the process of amending the relevant aspects of the labour legislation to give effect to the spirit of the conventions. At the time of writing the legal process was still under way, but with no set time frame.

\section{State-Media Relations}

The 1980s can be regarded as Botswana's decade of economic growth. It was then that the country was upgraded from a low-income to a middle-income country. Several independent newspapers emerged, to all intents and purposes as a spin-off of the economic growth. In the 1980s alone five independent newspapers made their appearance. They were the Botswana Guardian (1982), The Examiner (1982), the now defunct Mmegi Wa Dikgang (1984), the Botswana Gazette (1985), and the Mid-Week Sun (1989). The independent media continued to grow well into the 1990s, although not as rapidly as they had in the previous decade. The 1990s saw the formation of the Francistowner, renamed the Voice in 1992, and several other community or regional papers such as The Okavango Observer (1995) and the Mirror (1995). Recent additions include the Sunday Standard, the Sunday Tribune and The Echo. In addition, there is the Advertiser, a weekly that carries only advertisements and no news. Botswana also has two independent commercial radio stations, namely GABZ FM and Ya Rona FM.

All these developments are a far cry from the media landscape of the 1970s and 1980s in which Botswana had only one state-controlled newspaper, the Botswana Daily News, and one state-controlled radio station, Radio Botswana (both established in 1965 by the colonial administration). There are currently four radio stations (two of them state owned), two television stations, two daily newspapers, namely, the state owned Daily News and Mmegi, about 10 weeklies, three monthlies and several periodicals. Although the two privately owned radio stations are commercial, their coverage is restricted to a radius of $50 \mathrm{~km}$ from Gaborone, the capital city. By contrast, the state-owned RB2 is a national commercial radio station. 


\section{The political economy of the media in Botswana}

It is common cause that Botswana follows overtly pro-capitalist and free market economic and social policies, not withstanding the fact that, compared to other pro-capitalist free market economies, it has a considerable number of state owned enterprises (SOE). The reasons for this are historical. At the time of independence Botswana offered very little to attract the private sector. Soon after independence the new government took a policy decision to create enterprises to fill the gap in private sector provision (Mogalakwe 1997). According to Mogalakwe (1997) the SOEs were created in order to kickstart the economy, which had suffered almost 80 years of colonial neglect. It is a well-known Botswana government policy position that government's interventionist economic and social policies were intended to create conditions in which the private sector might thrive, and never to stifle private initiative (Mogalakwe 1997, p 39).

This policy position was reiterated in 1996 by the current president, Festus Mogae, when, as vice-president, he pointed out that the government was 'crowding out' the private sector with its active participation in the economy, and that government would start the process of 'hiving off' to the private sector some of the services provided by the state sector to create more room within the domestic economy for the private sector to grow (Mogalakwe 1997). Subsequently the Public Enterprises, Evaluation and Privatization Agency (PEEPA) was created to give effect to Botswana's commitment to private sector development and privatisation. But in a strange twist of logic, when it comes to the mass media the government has put considerable resources into the government-owned Daily News, RB1, RB2 and Botswana television, thus crowding out and stifling the independent press. For our purpose, we use the Daily News as a case study of how the government is stifling the growth of the independent press.

Advertising revenue (ad spend) constitutes the lifeblood of the independent media. It is usually the private sector, such as construction companies, financial institutions, insurance companies, car dealers, supermarkets, shops, and so on, which, in today's competitive economic environment, want to reach consumers and sell their products by regularly placing advertisements in newspapers and on radio and television. The decision about where to place an advertisement is usually influenced by a newspaper's circulation figures, a radio station's listenership, or a TV channel's viewership. In addition to looking for a vehicle that can help it reach the maximum number of consumers the private sector wants to do that as cheaply as possible.

As Table 1 shows, about 573500 copies of newspapers circulate in Botswana each week. The government-owned Daily News, published from Monday to Friday, excluding public holidays, accounts for about 325000 (54\%) of this circulation. 
Table 1

\begin{tabular}{|l|c|c|c|}
\hline Newspaper & Weekly sales & $\begin{array}{c}\% \text { market } \\
\text { share (circulation) }\end{array}$ & $\begin{array}{c}\% \text { market } \\
\text { share(ad spend) }\end{array}$ \\
\hline Daily News & 325000 & 54 & 25 \\
\hline The Advertiser & 90000 & 15 & 10 \\
\hline Mmegi & 39500 & 8 & 16 \\
\hline The Voice & 28000 & 5 & 10 \\
\hline The Botswana Guardian & 18900 & 4 & 5 \\
\hline The Midweek Sun & 18600 & 3 & 10 \\
\hline The Monitor & 18000 & 3 & 11 \\
\hline The Gazette & 16500 & 4 & 100 \\
\hline Others (combined) & 19000 & $\mathbf{1 0 0}$ & 5 \\
\hline Total & $\mathbf{5 7 3 5 0 0}$ & & 4 \\
\hline
\end{tabular}

With a daily circulation of about 65000 , the Daily News is the most widely read and therefore most influential paper in the country. Because it is owned by government it is regarded as reliable because any information that comes from government is believed to be accurate.

The Daily News's circulation is followed by that of the advertisement-only Advertiser, with a circulation of about 90000 per week, and, at a distant third place, by the Voice, with a weekly circulation of about 28000 .

Given all the advantages enjoyed by the Daily News it becomes clear that Botswana's much-vaunted independent and free press is, in fact, a mere formality. The independent press has to struggle to keep its head above water. In the area of mass communications the Botswana government competes directly with the private sector and the independent newspapers are no match for the massive human and material resources and logistical capacity available to the governmentowned newspaper, courtesy of the Botswana taxpayer. The environment in which the private sector media in Botswana operate reveals that Botswana's ideological commitment to private sector development and free enterprise has been severely tested and found wanting.

The Daily News is, in effect, Botswana's only national newspaper, covering almost the entire country through a network of bureaux and correspondents 
operating under the government-owned and controlled press agency the Botswana Press Agency (Bopa). Bopa correspondents, although qualified journalists, operate under terms and conditions of service which effectively make them civil servants. Bopa staffers, as, indeed, Daily News staffers, are governed by the Public Service Act and the General Orders. More importantly, they are paid from public funds and not from the profits of the newspaper. Since the mandate of the Daily News is to promote government policy, it follows that it is inclined to glorify the government and, by extension, the ruling party. The other advantage it enjoys is that it does not have the normal overheads, since all these are taken care of from public funds.

In 2001/2002 the government of Botswana adopted a policy decision to 'commercialise' the Daily News, going against clearly stated government policy objectives of encouraging the private sector to develop. The commercialisation of the newspaper meant, in effect, embarking on aggressive marketing to take advertising revenue away from the independent press, which depends on it to pay its overheads and make profits for its shareholders. According to recent estimates the Daily News now accounts for about 80 per cent of government ad spend and 25 per cent of national ad spend. It must also be noted that the Daily News 'Advertising Department' comprises civil servants who are paid from public funds. The question is why this is so.

It began in April 2001 when the Botswana government issued economic sanctions against the Botswana Guardian and its sister publication, the Midweek Sun. The sanctions were announced in a circular letter from the Office of the President to all ministries and departments, parastatals and other private companies in which government was a shareholder, instructing them to cease advertising in the two newspapers with immediate effect. The addressees were, however, allowed to use their discretion in cases where contracts had already been signed (Guardian 4 May 2001). As can be expected, the announcement of economic sanctions against these newspapers was met with shock and disbelief, especially since it came from a government that is a key player in the economy in general and the media in particular.

The Botswana government has always had an uneasy relationship with the independent press. The influence of the private media in promoting governance was felt mainly in the 1990s when it exposed cases of corruption at the then Ministry of Local Government and Land and at the Botswana Housing Corporation, a state-owned corporation (Good 2002; Maundeni, Molomo, OseiHwedie, Taylor \& Whitman 2002; Taylor 2003; Osei-Hwedie \& Sebudubudu 2004). As Good (2002, p 14) argued 'the mismanagement in the Ministry of Local Government and the BHC (Botswana Housing Corporation) came to light through public controversy fueled by good investigative reporting in the independent 
press. Internal government checking mechanisms were either absent or ineffective'.

Although the private media perform this important function, the relationship between them and the government has not always been cordial. The independent media have been accused of aligning with or being biased towards opposition parties. They have also been requested to respect national security (Grant \& Egner 1989). The media thus operate mindful of 'the threat of government surveillance and control' (Taylor 2003, p 219). Although the government refused to disclose the reasons for the sanctions it is generally assumed that the last straw in its uneasy relations with the independent press came when the Botswana Guardian published an obviously sensational story about the growing influence of Botswana's Vice-President, General Ian Khama. The paper speculated that President Mogae's image was diminishing while that of General Khama was growing. The story was headlined 'The Shrinking President', with a diminutive photograph of President Mogae next to a towering picture of General Khama.

The Guardian took the matter to the high court, asking that the directive from the Office of the President be set aside. In his affidavit, the editor of the newspaper listed about 12 parastatals that had stopped placing advertisements in the two newspapers. The editor also alleged that government's decision was politically motivated and would have the effect of closing down the newspapers. When the judge finally ruled on the matter he found against government and, in effect, 'ordered the government to suspend its decision to cease advertising in the two newspapers' (Botswana Daily News 19 September 2001).

The judgement was a huge embarrassment to government and prompted its decision to find another way of silencing the independent press: by commercialising the Daily News and positioning it as a rival and competitor, in the hope that eventually the independent press would bleed to death.

The reasons for the government's actions should, perhaps, be seen within the context of the independent press in any democracy - a vital institution of civil society caught between the role of watchdog and that of exposing the vices of a government. In performing this role it is viewed as an agency for change, inspiring discussion among the electorate; something that may not augur well for the government of the day. On the other hand, the mass media can also be used as an agency for control; extolling the virtues of government polices. The uneasy relationship between the Botswana government and the independent press and the efforts of the government to crowd out the independent press must be seen as the battle for the hearts and minds of the electorate. The question is to what extent it can really be said that Botswana's electorate is well informed. It is probably small wonder that the same party and government have been in office for the past 40 years. 


\section{CONCLUSION}

The paper has sought to examine state-civil society relations in Botswana against the backdrop of the country's much vaunted democracy. To this end, four institutions of civil society, namely Emang Basadi (a women rights advocacy organisation), Ditshwanelo (a human rights organisation), trade unions, and the media were selected for examination.

The examination has revealed that some institutions of civil society, such as human rights or women's organisations, are doing relatively well, in sharp contrast to others such as labour unions and the independent media, which have been tightly controlled.

Why does Botswana allow some institutions to flourish while putting a variety of obstacles in the way of others? The answer lies in the fact that states invariably seek to control and limit the activities of civil society, or at least to construct boundaries within which these activities take place. Those institutions which, like Emang Basadi and Ditshwanelo, opt to work within the set boundaries are successful in most cases because they do not pose a threat to the interests of the state and are perceived as compliant and playing only a legitimising role.

On the other hand, there are institutions that try to cross state-created boundaries and bring about a 'new order'. Such institutions, represented in our analysis by the trade union movement and the independent media, are perceived as a threat to the status quo.

The independent press, dubbed the 'fourth estate', heads the list of threats to the status quo because of its tendency to 'expose' the fact that the emperor has no clothes. In the above examination of state-civil society in Botswana, the independent press has emerged as the worst off. The fact that the government has decided, in the case of the media, to abandon its cherished principle of creating conditions for the private sector to grow, instead competing directly with a fledgling independent press, underlines how this institution of civil society in particular can be a source of great irritation, even in a country that claims to have democracy and good governance.

In a multiparty system such as that in Botswana where the war for hearts and minds is so vital, the independent press plays a crucial role in informing citizens about their government's activities and the alternatives presented by the opposition. It may not be such a mystery why the ruling BDP has won every election since 1965. It is only now, with the advent of the independent press, that citizens are able to compare the parties. But, as we have shown, the government continues to keep the media under very tight control. 
Balogun, M J. 1997. 'Enduring Clientelism, Governance Reform and the Leadership Capacity: A Review of the Democratization Process in Nigeria'. Journal of Contemporary African Studies 15 (2).

Botswana Daily News. 19 September 2001.

Botswana Government. 1999. Report to the Vice-President and Minister of Presidential Affairs and Public Administration on the 1999 General Elections. Gaborone: The Independent Electoral Commission

Botswana Government. 2004. Report to the Minister of Presidential Affairs and Public Administration on the 2004 General Elections. Gaborone: The Independent Electoral Commission.

Carroll, T \& B W Carroll. 2004. 'The Rapid Emergence of Civil Society in Botswana'. Commonwealth \& Comparative Politics 42(3).

Cilliers, J. 2004. Human Security in Africa: A Conceptual Framework for Review. Cape Town: Africa Human Security Initiative.

Diamond, L.1994. 'Rethinking Civil Society: Toward Democratic Consolidation'. Journal of Democracy 5(3).

Diamond, L, J J Linz \& S Lipset (eds). 1988. Democracy in Developing Countries: Volume 2 Africa. Boulder: Lynne Rienner Publishers.

Ditshwanelo - The Botswana Centre for Human Rights. www.ditshwanelo.org.bw.

Good, K. 2002. 'Rethinking non-accountability and Corruption in Botswana'. Africa Insight 32(3).

Grant, S and B Egner. 1989. 'The Private Press and Democracy'. In J Holm and P Molutsi (eds). Democracy in Botswana. Gaborone: Macmillan Botswana.

Gyimah-Boadi, E. 1997. 'Civil Society in Africa'. In L Diamond, M Plattner, Y Chu and H Tien (eds). Consolidating the Third Wave Democracies. Baltimore: The John Hopkins University Press.

Holm, J. 1989. 'How Effective are Interest Groups in Representing their Members?'. In J Holm \& P Molutsi (eds). Democracy in Botswana. Gaborone: Macmillan Botswana.

- 1996. 'Development, Democracy and Civil Society in Botswana'. In A Leftwich (ed). Democracy and Development: Theory and Practice. Cambridge: Polity Press.

_ \& P Molutsi. 1992. 'State-civil society relations in Botswana'. In G Hyden, G and M Bratton (eds). Governance and Politics in Africa. London: Lynne Rienner Publishers.

Leftwich, A. 1994. 'Governance, the State and Politics of Development'. Development and Change 25. 
Lekorwe, M H. 1998. 'Local Government, interest groups and civil society'. In K R Hope \& G Somolekae (eds). Public Administration and Policy in Botswana. Cape Town: Juta \& Co.

Maundeni, Z. 2004. 'Mutual Criticism and State/society interaction in Botswana'. Journal of Modern African Studies 42(4).

- 2005. 'Civil Society and Democracy in Botswana'. In Z Maundeni (ed). 40 Years of Democracy in Botswana: 1965-2005. Gaborone: Mmegi Publishing House.

—, M G Molomo, B Z Osei-Hwedie, I Taylor \& S Whitman. 2002. 'Democratic Governance and Common Security in Southern Africa: The Case of Botswana'. Department of Political and Administrative Studies. SADSEM R/IDRC Research Project.

Molomo, M \& G Somolekae. 1998. 'Making a Difference: NGOs, good governance and service delivery'. In R K Hope \& G Somolekae (eds). Public Administration and Policy in Botswana. Cape Town: Juta \& Co.

Mogalakwe, M. 1997. The State and Organised Labour in Botswana - 'Liberal Democracy' in emergent capitalism. Ashgate: Aldershot.

Osei-Hwedie, B Z. 2003. 'Awakening of Civil Society: In Defense of Transparency and Accountability, The Case of Zambia'. Africa Notes.

— \& D Sebudubudu. 2004. 'Strengthening Parliamentary Democracy in SADC Countries: Botswana country report'. In T Hughes (ed). Parliaments of the South. Braamfontein: The South African Institute of International Affairs.

Otsheleng, K. 2006. The Voice 2 June 2006.

Samatar, A I. 1999. An African Miracle: State and Class leadership and Colonial legacy in Botswana Development. Portsmouth, NH: Heinemann.

Sebudubudu, D. 2003. 'Corruption and its Control in Botswana'. Botswana Notes and Records 35.

— \& B Z Osei-Hwedie. 2005. Democratic Consolidation in SADC: Botswana's 2004 Elections. Johannesburg: EISA.

—. 2006. 'Botswana: Democracy Curtailed?'. In E Sidiropoulous (ed). South African Yearbook of International Affairs, 2005. Johannesburg: The South African Institute of International Affairs.

Selolwane, D O. 2004. Feminist Africa 3. www.Feministafrica.org.

Somolekae, G. 1998. 'Democracy, Civil Society and Governance in Africa: The Case of Botswana'. http:/ / unpan1.un.org/intradoc/groups/public/ documents / CAFRAD / UNPAN009287.pdf.

Schraeder, P J. 2000. African Politics and Society. Boston: Bedford / St. Martins. Stedman, S J. 1993. 'Introduction'. In The Political Economy of Democratic Development. Boulder, Colorado: Lynne Rienner Publishers. 
Taylor, I. 2003. 'As Good as it gets? Botswana's Democratic Development'. Journal of Contemporary African Studies 21(2).

Tsie, B. 1996. 'The Political Context of Botswana`s Development Performance'. Journal of Southern African Studies 22(4).

United Nations Development Programme. 1997. Botswana Human Development Report 1997: Challenges for sustainable Human Development. Gaborone: TA Publications (Botswana).

Zuern, E. 2000. 'The Changing Roles of Civil Society in African Democratisation Processes'. In H Solomon \& I Liebenberg (eds). Consolidation of Democracy in Africa: A View from the South. Hampshire: Ashgate Publishing Limited. 